\title{
TAFSIR MAKNA NEGARA HUKUM DALAM PERSPEKTIF UNDANG-UNDANG DASAR NEGARA REPUBLIK INDONESIA TAHUN 1945
}

\author{
Janpatar Simamora \\ Fakultas Hukum Universitas HKBP Nommensen Medan \\ e-mail: patarmora_81@yahoo.co.id
}

\begin{abstract}
According to Article 1 paragraph (3) of constitution 1945 stated that "Indonesia is a state of law". However, there was no explanation of the meaning a state of law by the constitution 1945. While, conception the state of law always refers to two different streams, namely state of law in meaning rechtsstaat and state of law within the meaning of the rule of law. To answer meaning of state of law by the constitution 1945, it is necessary to understand subtance "Preamble", in particular the fourth paragraph of about the goal of the state of Republic Indonesia.
\end{abstract}

Keywords: state of law, Pancasila, Constitution 1945.

\begin{abstract}
Abstrak
Menurut Pasal 1 ayat (3) UUD NRI Tahun 1945 disebutkan bahwa "negara Indonesia adalah negara hukum". Namun demikian, tidak ditemukan uraian lebih lanjut tentang makna negara hukum menurut UUD NRI Tahun 1945. Sementara dalam perjalanan historisnya, konsepsi negara hukum selalu bertitik tolak pada dua aliran berbeda, yaitu negara hukum dalam arti rechtsstaat dan negara hukum dalam arti the rule of law. Untuk menjawab apa sesungguhnya makna negara hukum menurut UUD NRI Tahun 1945, maka perlu dipahami secara utuh dan mendalam substansi Pembukaan, khususnya alinea keempat tentang tujuan yang hendak dicapai negara Republik Indonesia.
\end{abstract}

Kata Kunci: negara hukum, Pancasila, UUD NRI Tahun 1945,

\section{Pendahuluan}

Salah satu amanat reformasi yang bergulir pada tahun 1997-1998 adalah dilakukannya perubahan terhadap Undang-Undang Dasar Tahun 1945. ${ }^{1}$ Guna merespons hal dimaksud, maka dilakukanlah perubahan demi perubahan terhadap sejumlah ketentuan dalam UUD. Sebagai hasilnya, hanya dalam kurun waktu 4 tahun (1999-2002), telah terjadi 4 (empat) kali proses amandemen terhadap Undang-Undang Dasar 1945 (UUD 1945). Sejumlah perubahan dimaksud pada akhirnya telah membawa perubahan mendasar dalam sistem ketatanegaraan Republik Indonesia. Hal inilah yang kemudian dimaknai banyak pihak sebagai bentuk reformasi konstitusi (constitutional reform).

Sekian banyak agenda perubahan yang direalisasikan melalui perubahan UUD NRI 1945,

Istilah UUD 1945 ditujukan sebagai nomenklatur atau penamaan terhadap UUD 1945 sebelum perubahan. semangat untuk mengokohkan Negara Kesatuan Republik Indonesia sebagai negara hukum merupakan salah satu agenda penting yang mendapat perhatian serius banyak kalangan ketika itu. Oleh sebab itu, ketentuan mengenai negara hukum semakin dipertegas dalam UUD setelah perubahan. Tentu harus diakui bahwa dalam upaya mewujudkan negara hukum sebagaimana yang dicita-citakan dalam UUD NRI 1945 akan dapat direalisasikan bila seluruh proses penyelenggaraan pemerintahan benar-benar didasarkan pada kaidah-kaidah yang tertuang dalam konstitusi atau UUD.

Di Amerika Serikat dalam praktiknya, perubahan konstitusi dapat juga terjadi melalui peran The Supreme Court (Mahkamah Agung). Oleh karena itu, The Supreme Court disebut juga sebagai agent of constitutional change mengingat perannya dalam mengubah konstitusi melalui reinterpretasi peradilan. Hal ini me- 
munculkan pendapat berbeda. Para pendukung The Supreme Court sebagai agen perubahan konstitusi mengatakan bahwa The Supreme Court harus menafsirkan konsep konstitusi dalam rangka mengakomodir perubahan zaman. Di sisi lain, pihak yang tidak mendukung hal tersebut berpendapat bahwa penafsiran seperti itu tidak sah dan tidak sesuai dengan constitutionalism. ${ }^{2}$ Namun demikian, dalam Article $V$ Konstitusi Amerika Serikat hanya menetapkan dua cara berbeda dalam mengubah konstitusinya. Pertama, allows Congress to propose amendments when such amendments are approved by at least a two-thirds vote in both houses. Kedua, This method requires Congress to call a constitutional convention to propose amendments when two thirds of the States apply for such a convention. ${ }^{3}$

Ide maupun konsep negara hukum pada umumnya dimaksudkan dalam rangka menghinadari negara atau pemerintah dari perbuatan sewenang-wenang. Karena bagaimanapun, bahwa suatu pemerintahan yang tidak dikontrol dengan perangkat hukum yang tegas dan konkret akan sangat rentan dengan berbagai bentuk penyimpangan dan penyalahgunaan kekuasaan. Bahkan pada era modern sekarang, dapat dikatakan bahwa merupakan suatu negara yang sangat relevan dan ideal bila kemudian segala rangkaian kegiatan kenegaraannya didasarkan pada mekanisme hukum yang jelas dan tegas.

Dilakukannya rangkaian perubahan terhadap UUD 1945 tentu tidak terlepas dari sejumlah persoalan yang melatarbelakanginya. Adapun dasar pemikiran yang melatarbelakangi perubahan terhadap UUD 1945 adalah sebagai berikut. Pertama, UUD 1945 membentuk struktur ketatanegaraan yang bertumpu pada kekuasaan tertinggi di tangan MPR yang sepenuhnya melaksanakan kedaulatan rakyat; kedua, UUD 1945 memberikan kekuasaan yang sangat besar kepada pemegang kekuasaan eksekutif

Lihat dalam Joel K. Goldstein, "Constitutional Change, Originalism and The Vice Presidency", Journal of Constitutional Law, Vol. 16 No. 2, Nov. 2013. University of Penn-sylvania Law of School, Philadelphia, hlm. 370.

3 James Kenneth Rogers, "The Other Way to Amend the Constitution: The artikel $V$ Constitutional Convention Amendment Process", Harvard Journal of Law \& Public Policy, Vol. 30 No. 3, Summer 2007, hlm. 1005. (presiden). Sistem yang di-anut oleh UUD 1945 adalah dominan eksekutif (executive heavy), yakni kekuasaan dominan berada di tangan presiden. Pada diri presiden terpusat kekuasaan menjalankan pemerintahan (chief executive) yang dilengkapi dengan berbagai hak-hak konstitusional yang lazim disebut sebagai hak prerogatif seperti memberi grasi, amnesti, abolisi dan rehabilitasi serta kekuasaan legislatif, karena memiliki kekuasaan mem-bentuk undangundang; ketiga, UUD 1945 mengandung pasalpasal yang terlalu 'luwes', sehingga dapat menimbulkan lebih dari satu penafsiran; keempat, UUD 1945 terlalu banyak memberi kewenangan kepada kekuasaan presiden untuk mengatur hal-hal penting dengan undang-undang. Hal ini berpotensi menimbulkan kondisi dimana presiden dapat merumuskan hal-hal penting sesuai dengan kehendaknya dalam undang-undang; dan kelima, rumusan UUD 1945 tentang semangat penyelenggaraan negara belum cukup didukung ketentuan konstitusi yang memuat aturan dasar tentang kehidupan yang demokratis, supremasi hukum, pemberdayaan rakyat, penghormatan terhadap hak asasi manusia dan otonomi daerah. ${ }^{4}$

Guna menuntaskan sejumlah persoalan itu dan dalam rangka penyempurnaan terhadap aturan dasar penyelenggaraan negara secara demokratis dan moder, perlu dilakukan beberapa hal, ${ }^{5}$ seperti: pemisahan dan/atau pembagian kekuasaan yang lebih tegas, penerapan sistem checks and balances yang lebih ketat dan transparan serta pembentukan lembaga-lembaga negara yang baru untuk mengakomodir perkembangan kebutuhan bangsa dan tantangan zaman, ${ }^{6}$ maka digulirkanlah sejumlah perubahan terhadap berbagai ketentuan dalam UUD 1945. Adapun rincian perjalanan waktu perubahan UUD 1945 yang telah diubah sebanyak 4

MPR RI, 2012, Panduan Pemasyarakatan Undang-Undang Dasar Negara Republik Indonesia Tahun 1945 dan Ketetapan Majelis Permusyawaratan Rakyat, Edisi Revisi, Cetakan Kesebelas, Jakarta: Sekretariat Jen-deral MPR $\mathrm{RI}, \mathrm{h} \mathrm{lm}$. 9-12.

Ibid, hlm. 13

6 Maruarar Siahaan, “Uji Konstitusionalitas Peraturan Perundang-undangan Negara Kita: Masalah dan Tantangan”, Jurnal Konstitusi, Vol. 7 No. 4, Edisi Agustus 2010, Jakarta: Mahkamah Konstitusi Republik Indonesia, hlm. 
(empat) kali perubahan, yaitu perubahan pertama dilakukan pada tahun 1999, perubahan kedua pada tahun 2000, perubahan ketiga pada tahun 2001 dan perubahan keempat pada tahun 2002.

Sejumlah materi muatan yang terkandung dalam UUD 1945 juga turut mengalami perubahan yang cukup signifikan, baik dalam ben-tuk penambahan maupun pengurangan. Kalau sebelum diubah, UUD NRI Tahun 1945 terdiri dari 16 Bab, 37 Pasal, 49 Ayat, 4 Pasal Aturan Peralihan dan 2 ayat Aturan Tambahan, maka setelah perubahan, komposisi tersebut menjadi $21 \mathrm{Bab}$, 73 Pasal, 170 ayat, 3 Pasal Aturan Peralihan dan 2 Pasal Aturan Tambahan. Dari perbandingan data tersebut, perubahan yang cukup signifikan dapat dilihat dari adanya penambahan ayat sekitar 121 ayat. Hal ini dilakukan guna mengakomodir berbagai sisi kehidupan ketatanegaraan yang selama ini dipandang belum di atur secara maksimal dalam konstitusi, sehingga dengan demikian, maka upaya merealisasikan cita-cita reformasi dan cita-cita negara hukum, khususnya melalui jalur konstitusi akan dapat diwujudkan secara nyata atau setidaknya diakomodir secara yuridis.

Seluruh rangkaian perubahan dimaksud tentunya dapat dimaknai dan diklasifikasikan sebagai langkah reformasi konstitusi (constitutional reform), karena faktanya bahwa perubahan yang terjadi tidak hanya sebatas bentuk formal, melainkan juga mengarah pada persoalan-persoalan ketatanegaraan yang sangat substansial. UUD NRI Tahun 1945 dari segi aspek sistematika, sebelum diubah terdiri dari 3 (tiga) bagian dan penamaan, yaitu: Pembukaan (Preambule), Batang Tubuh dan Penjelasan. Setelah perubahan, bagian-bagian dan penamaan UUD NRI Tahun 1945 terdiri dari 2 (dua) bagian, yaitu: Pembukaan dan pasal-pasal (sebagai pengganti istilah Batang Tubuh). Adapun untuk bagian Penjelasan telah dihilangkan dengan pertimbangan bahwa seluruh ketentuan pokok yang tercantum dalam Penjelasan sudah diakomodir dalam bagian pasal-pasal. Selain itu, penghapusan bagian Penjelasan juga dimaksudkan guna menghindari kesulitan dalam menentukan status bagian Penjelasan dari sisi sumber hukum dan tata urutan peraturan perundang-undangan. ${ }^{7}$

Diadopsinya ketentuan tentang negara hukum dalam Pasal 1 ayat (3) UUD NRI Tahun 1945, di mana sebelumnya hanya diatur pada bagian Penjelasan UUD 1945 sebelum perubahan pada dasarnya tidak dibarengi dengan penjelasan lanjutan akan makna negara hukum itu sendiri. Berbeda halnya pada saat pengaturan istilah negara hukum dalam UUD 1945 sebelum perubahan yang ditempatkan pada bagian Penjelasan, tepatnya pada bagian Sistem Pemerintahan Negara yang secara langsung menegaskan bahwa Negara Indonesia berdasar atas hukum (rechtsstaat), tidak berdasarkan kekuasaan belaka (machtsstaat).

Sebagaimana diketahui bahwa konsepsi tentang negara hukum selalu berkiblat pada dua tradisi hukum berbeda, yaitu common law system dan civil law system. Keduanya memiliki ciri serta aspek penekanan yang berbeda antara satu dengan lainnya. Kemudian, apa sesungguhnya makna negara hukum sebagaimana dimaksud dalam Pasal 1 ayat (3) UUD NRI Tahun 1945. Apakah negara hukum dalam pengertian common law system atau civil law system atau bahkan negara hukum dalam versi lain menurut tradisi hukum yang berkembang di tanah air. Sejumlah persoalan inilah yang akan menjadi objek pembahasan lebih lanjut dalam tulisan ini.

\section{Pembahasan}

Konsepsi Awal Pemikiran Tentang Negara Hukum

Akar konsepsi pemikiran tentang negara hukum dalam sejarah dimulai sejak Magna Charta 1215, hanya saja baru kemudian pada abad ke-XVII, perbincangan tentang negara hukum sudah mulai serius dilakukan. ${ }^{8}$ Lahirnya pemikiran tentang negara hukum adalah sesungguhnya tidak dapat dilepaskan dari adanya tindakan sewenang-wenang yang digulirkan oleh

MPR RI, op.cit., hlm. 14.

Susi Dwi Harijanti, 2011, Negara Hukum dalam UndangUndang Dasar 1945, dalam "Negara Hukum yang Berkeadilan: Kumpulan Pemikiran dalam Rangka Purnabakti Prof.Dr.H.Bagir Manan, SH., MCL", Cetakan Pertama, Bandung: PSKN FH UNPAD, hlm. 82. 
penguasa kala itu. Bahkan kemudian, konsepsi negara hukum dipandang sebagai bentuk reaksi atas tindakan sewenang-wenang yang dilakukan penguasa.

Atas dasar itulah, maka kemudian pembatasan kekuasaan penguasa menjadi sangat urgen untuk dilakukan melalui perangkat hukum agar pemerintahan yang sedang memegang kendali kekuasaan suatu negara dapat terkendali. Cita negara hukum untuk pertama kalinya dikemukakan oleh seorang filosof Yunani bernama Plato. Plato, dalam bukunya yang berjudul Nomoi, menggambarkan bagaimana pentingnya posisi hukum dalam mengatur negara dengan menyatakan bahwa penyelenggaraan pemerintahan yang baik adalah pemerintahan yang diatur oleh hukum. Pandangan Plato ini cukup mengisyaratkan bagaimana sesungguhnya peran penting hukum dalam mengatur kehidupan berbangsa dan bernegara.

Sesungguhnya pada awal pemikirannya, Plato dalam bukunya berjudul Republic, menginginkan supaya negara diperintah oleh seorang raja dari kalangan filosof dengan maksud bahwa negara akan dapat diperintah secara bijak tanpa harus tunduk pada mekanisme hukum. Namun dalam perjalanannya bahwa apa yang dicita-citakan Plato sejak awal ternyata sangat sulit untuk direalisasikan. Karena faktanya bahwa negara yang diperintah oleh seorang filosof yang bijak tidak selamanya berjalan sesuai dengan yang diharapkan. Oleh karena itulah maka Plato kemudian menegaskan bahwa sesungguhnya pilihan terbaik dalam mengelola negara harus tunduk pada aturan-aturan yang berlaku.

Pemikiran Plato dikembangkan oleh muridnya yang bernama Aristoteles. Ketika itu, Aristoteles berusaha mewariskan ajaran gurunya dengan melakukan penyempurnaan terhadap pengertian negara hukum dengan mengatakan bahwa suatu negara yang baik adalah negara yang dijalankan menurut konstitusi serta berkedaulatan hukum. Menurut Aristoteles, sesungguhnya yang memerintah dalam negara bukanlah manusia, melainkan pikiran yang adil. Di sisi lain, kesusilaan berperan penting guna menentukan baik buruknya suatu hukum. Manusia harus dididik menjadi warga negara yang baik, dengan demikian maka manusia akan ditempa menjadi warga negara yang bersikap adil dalam kehidupannya.

Immanuel Kant menjelaskan makna negara hukum sebagai penjaga malam, artinya bahwa tugas negara hanya sebatas menjaga dan melindungi hak-hak rakyat. Hanya saja, bila dilakukan pengkajian lebih lanjut bahwa sesungguhnya gagasan ini masih mengandung sejumlah kelemahan tersendiri, karena dalam praktik yang terjadi selama ini ada kalanya negara tidak hanya bertugas menjaga dan melindungi hak-hak rakyat, namun harus turut campur tangan dan kondisi dan hal-hal tertentu. Tentunya dengan catatan bahwa sepanjang campur tangan tersebut dimaksudkan dalam rangka mewujudkan tercapainya keadilan dan kesejahteraan bagi rakyatnya. Oleh sebab itu, maka dapat dikatakan bahwa konsepsi negara hukum sebagaimana yang dicita-citakan oleh Immanuel Kant sesungguhnya merupakan konsepsi pemaknaan negara hukum dalam arti sempit, klasik atau kuno, yaitu negara dimana tugas negara hanya menjaga keamanan dan ketenteraman dengan membuat hukum, melaksanakan hukum, dan mengawasi pelaksanaan hukum tersebut, sedangkan tugas-tugas lainnya, seperti tugas dalam bidang pendidikan dan pengajaran, keagamaan, pertanian dan tugas lainnya menjadi tugas para warga negara perorangan. Kemungkinan besar, Immanuel Kant menciptakan pengertian negara hukum dalam makna sempit dikarenakan pengaruh perkembangan paham individualisme, yaitu paham yang mengutamakan kepentingan perorangan dan paham liberalisme, yaitu paham yang mengutamakan kebebasan perorangan. Sementara sejumlah paham dimaksud tidak selamanya akan selalu menjadi pilihan terbaik bagi suatu negara, khususnya pada era modern yang lebih menonjolkan kehidupan demokratis saat ini.

Apaila kemudian kembali pada pandangan Aristoteles, dapat dipahami bahwa negara hukum memiliki keterkaitan yang sangat erat dengan keadilan dan konstitusi. Oleh sebab itulah, maka berbagai negara, termasuk Indonesia menempatkan pengaturan konsepsi negara hukum dalam konstitusinya. Hal ini dilakukan agar pe- 
negasan konsep negara hukum dapat terpatri dalam kehidupan kenegaraan dan menjadi landasan yang sangat kuat dalam menjalankan roda pemerintahan dan kehidupan bernegara. Selain itu, penempatan negara hukum dalam konstitusi dapat dimaknai sebagai upaya melembagakan dan membudayakan ketaatan terhadap hukum dalam menjalankan roda pemerintahan. ${ }^{9}$

Konsep negara hukum sering diterjemahkan dengan berbagai istilah yang berbeda-beda seperti the rule of law, rechtsstaat, etat de droit atau estado de derecho. ${ }^{10} \mathrm{Di}$ negaranegara Eropa Continental, konsep negara hukum disebut dengan istilah rechtsstaat. Istilah rechtsstaat adalah merupakan bahasa Belanda yang memiliki makna dan pengertian sejajar dengan rule of law di negara-negara yang menganut sistem Anglo Saxon. Di Indonesia dikenal dengan istilah "negara hukum", yang dalam bahasa Jerman disebut dengan istilah "rechtsstaat" atau dalam bahasa Perancis disebut dengan istilah "Etat de Droit".

Sebagaimana dikemukakan oleh Ni'matul Hud, ${ }^{11}$ bahwa Dilihat dari latar belakang dan sistem hukum yang menopangnya, terdapat perbedaan antara konsep rechstsaat dengan konsep rule of law, meskipun dalam perkembangannya dewasa ini tidak lagi dipermasalahkan lagi perbedaan antara keduanya dan keduanya berjalan dengan sistem sendiri, karena pada dasarnya kedua konsep itu mengarah pada satu sasaran yang utama, yaitu pengakuan dan perlindungan terhadap hak-hak asasi manusia. Konsep rechsstaat lahir dari suatu perjuangan menentang absolutisme sehingga sifatnya revolusioner, sebaliknya konsep rule of law berkembang secara evolusioner. ${ }^{12}$

Konsep rechsstaat bertumpu atas sistem hukum kontinental yang disebut civil law yang

9 Janpatar Simamora, 2013, Mendesain Ulang Model Kewenangan Judicial Review di Indonesia, Cetakan Pertama, Yogyakarta: Capiya Publishing, hlm. 41.

10 Susi Dwi Harijanti, op.cit., hlm. 80.

11 Dayanto, "Rekonstruksi Paradigma Pembangunan Negara Hukum Indonesia Berbasis Pancasila", Jurnal Dinamika Hukum, Vol. 13 No. 3, Edisi September 2013, Purwokerto, Fakultas Hukum Universitas Jenderal Soedirman, hlm. 500 .

12 Ibid., berkarakter administratif, sedangkan konsep rule of law bertumpu atas sistem hukum yang disebut common law yang berkarakter judicial ${ }^{13}$ atau peradilan. Konsep rechtsstaat diawali dari sistem Romawi Jerman pada dasarnya mengembangkan kaidah hukum yang sistematis, doktrinal, dan berdasarkan perundang-undangan yang dibuat oleh lembaga legislatif, sedangkan konsep the rule of the law yang dilatar belakangi oleh sistem common law, norma hukumnya tidak dirumuskan secara sistematis dan doctrinal. Jadi, ciri common law terletak pada normanya yang bersifat konkret yang dilahirkan melalui suatu putusan hakim. ${ }^{14}$ Disini tampak bagaimana pentingnya fungsi peradilan dalam sistem common law. Makna esensial dari the rule of law adalah pembatasan kekuasaan terhadap pemerintah oleh hukum (termasuk konstitusi karena konstitusi adalah hukum). Asas the rule of law juga berusaha untuk memastikan bahwa pembatasan kekuasaan terhadap pemerintah oleh hukum mampu terjadi secara faktual. ${ }^{15}$

Merujuk pada apa yang dikemukakan oleh A.V. Dicey bahwa setidaknya terdapat 3 (tiga) arti dari negara hukum dalam arti rule of law. Pertama, supremasi absolut terletak pada hukum, jadi bukan pada tindakan penguasa; kedua, berlakunya prinsip persamaan di muka hukum (equility before the law), di mana semua orang harus tunduk kepada hukum; dan ketiga, konstitusi merupakan dasar atau landasan dari segala hukum yang ada bagi negara yang bersangkutan.

Kemudian bila dibandingkan dengan pendapat ahli lainnya, yaitu Hans Kelsen, memberikan argumentasi bahwa dalam kaitan negara hukum yang juga merupakan negara demokratis setidak-tidaknya harus memiliki 4 (empat) syarat rechtsstaat. Pertama, negara yang kehidupannya sejalan dengan konstitusi dan undang-undang; kedua, negara yang mengatur mekanisme pertanggungjawaban atas setiap ke-

13 Ibid.,

14 Ibid., hlm. 500-501.

15 Titon Slamet Kurnia, “Konsep Negara Berbasis Hak sebagai Argumen Justifikasi Pengujian Konstitusionalitas Undang-undang”, Jurnal Konstitusi, Vol. 9 No. 3, Edisi September 2012, Jakarta: Mahkamah Konstitusi Republik Indonesia, hlm. 575. 
bijakan dan tindakan yang dilakukan oleh penguasa; ketiga, negara yang menjamin kemerdekaan kekuasaan kehakiman serta adanya peradilan adminstrasi negara; dan keempat, negara yang melindungi hak azasi manusia.

Berkaitan dengan posisi norma hukum dalam sebuah negara, Hans Kelsen menjelaskan bahwa norma-norma konstitusi yang mengatur pembentukan norma-norma umum yang harus diterapkan oleh pengadilan dan organ-organ penegak hukum lainnya bukanlah norma-norma yang lengkap dan berdiri sendiri. Pandangan Hans Kelsen itu tampaknya mengarahkan pemaknaan terhadap istilah negara hukum, khususnya pengertian konstitusi yang tidak dapat dimaknai hanya sebatas pengaturan hal-hal umum dan abstrak dalam kehidupan bernegara. Selain itu, ahli hukum lainnya yang turut memberikan pandangannya mengenai kriteria negara hukum adalah Friedrich Julius Stahl, yaitu seorang sarjana hukum Jerman dengan menjelaskan bahwa suatu negara hukum formal harus memenuhi persyaratan sebagai berikut: adanya pengakuan terhadap hak-hak asasi manusia; adanya pemisahan kekuasaan; pemerintahan dijalankan berdasarkan undang-undang; dan adanya pengadilan administrasi.

Ditemukannya beberapa perbedaan istilah dan pengertian serta ciri-ciri maupun kriteria terkait dengan negara hukum, namun dari keseluruhan pandangan yang ada tampat dengan jelas adanya upaya yang berusaha untuk menegaskan bahwa negara hukum adalah negara yang melandaskan setiap kehidupan kenegaraannya didasarkan pada mekanisme hukum yang jelas dan tegas. Selanjutnya, dalam proses pembentukannya bahwa hukum yang berlaku dalam negara hukum semestinya dirumuskan secara demokratis pula, ${ }^{16}$ artinya bahwa hukum yang terbentuk dan berlaku adalah hukum yang benar-benar dikehendaki oleh seluruh rakyat, bukan semata-mata dikehendaki oleh merekamereka yang memegang tampuk kekuasaan. Dengan pola pembentukan hukum yang demikian, maka upaya menciptakan negara hukum yang demokratis (democratise rechtsstaat)

16 Janpatar Simamora, op.cit., hlm. 43. akan dapat diwujudnyatakan dan direalisasikan dengan baik. ${ }^{17}$ Pada titik inilah perlu dipahami lebih lanjut bagaimana sesungguhnya keterkaitan antara negara hukum dan demokrasi. Seyogianya kedua elemen dimaksud dapat berjalan seirama agar kemudian upaya perwujudan negara hukum yang sesungguhnya dapat tercapai sesuai dengan yang dikehendaki rakyat suatu negara.

\section{Makna Negara Hukum dalam UUD 1945 sebe- lum Perubahan}

Sebagaimana dijelaskan sebelumnya pada bagian awal tulisan ini bahwa pengaturan mengenai Indonesia sebagai negara hukum dalam UUD 1945 sebelum perubahan tidak dimuat dalam bagian "Batang Tubuh" atau pasal-pasal. Pengaturannya hanya ditempatkan di bagian "Penjelasan", tepatnya pada bagian "Sistem Pemerintahan Negara", point pertama dengan bunyi "Indonesia ialah negara yang berdasar atas hukum (reschtsstaat), tidak berdasarkan kekuasaan belaka (machtsstaat)". Dengan bentuk pengaturan yang demikian, maka tentu dengan mudah akan dipahami bahwa negara hukum sebagaimana dimaksud dalam UUD 1945 sebelum perubahan adalah negara hukum yang mengarah pada konsep hukum rechtsstaat yang lahir dari konsep hukum Eropa Kontinental. Penegakan semacam ini sangat dibutuhkan agar kemudian tidak terbuka ruang penafsiran secara beragam terhadap makna negara hukum itu sendiri. Barangkali, hal ini akan menjadi salah satu kelebihan dari mekanisme pengaturan yang dituangkan dalam UUD 1945 sebelum perubahan.

Substansi lain yang turut diatur dalam bagian "Penjelasan" UUD 1945, khususnya pada "Sistem Pemerintahan" adalah: Sistem Konstitusional. Pada point ini dijelaskan bahwa pemerintahan berdasar atas sistem konstitusi (hukum dasar) tidak bersifat absolutisme (kekuasaan yang tidak terbatas). Selain itu disebutkan pula bahwa kekuasaan negara yang tertinggi ditangan MPR (Die gezatnte Staatgewalt liegi allein bei der Majelis). Adapun Kedaulatan Rakyat di-

17 Ibid., hlm. 43-44. 
pegang oleh suatu badan, bernama MPR, sebagai penjelmaan seluruh rakyat Indonesia (Vertretungsorgan des Willens des Staatsvolkes). Majelis ini menetapkan UUD dan menetapkan garis-garis besar haluan negara. Majelis ini mengangkat Kepala Negara (Presiden) dan Wakil Kepala Negara (Wakil Presiden). Majelis inilah yang memegang kekuasaan negara yang tertinggi, sedang Presiden harus menjalankan haluan negara menurut garis-garis besar yang telah ditetapkan oleh Majelis. Adapun Presiden yang diangkat oleh Majelis, bertunduk dan bertanggung jawab kepada Majelis. Ia ialah "mandataris" dari Majelis. la berwajib menjalankan putusan-putusan Majelis. Presiden tidak "neben", akan tetapi "untergeordnet" kepada Majelis. Selain itu, disebutkan pula bahwa Presiden ialah penyelenggara pemerintah negara yang tertinggi di bawah Majelis. Di bawah MPR, Presiden ialah penyelenggara pemerintah negara yang tertinggi. Dalam menjalankan pemerintahan negara, kekuasaan dan tanggungjawab adalah ditangan Presiden (concentration of power and responssibility upon the President). Presiden tidak bertanggungjawab kepada DPR. Di sampingnya Presiden adalah DPR. Presiden harus mendapat persetujuan DPR untuk membentuk undang-undang (Gesetzgebung) dan untuk menetapkan anggaran pendapatan dan belanja negara (Staatsbegrooting). Oleh karena itu, Presiden harus bekerja bersama-sama dengan Dewan, akan tetapi Presiden tidak bertanggung jawab kepada Dewan, artinya kedudukan Presiden tidak tergantung dari pada Dewan.

Jika kemudian dikaji dalam perspektif historisnya, maka dapat dipahami bahwa bangunan teori atau konsep negara hukum di Eropa Kontinental yang kemudian diadopsi dalam UUD 1945 sebelum perubahan sangat banyak terpengaruh oleh pemikiran Immanuel Kant, Hans Kelsen maupun sejumlah ahli hukum lainnya. Adapun perkembangan konsep negara hukum di Eropa Kontinental dapat dilihat antara lain di negara Jerman dan Perancis. ${ }^{18}$ Sebagaimana pernah ditulis Marjanne Termorshuizen-

18 Susi Dwi Harijanti, op.cit., hlm. 83.
Artz, ${ }^{19}$ bahwa di Jerman sendiri, negara hukum pada awalnya diartikan sebagai Gesetzeestaat yang menunjuk pada konsep minimal formal legality yang sangat menekankan pentingnya prinsip legalitas dan kemudian dipraktikkan pada masa sebelum Perang Dunia II. Sekalipun Immanuel Kant sering dianugerahi gelar sebagai bapak spiritual konsep rechtsstaat, namun demikian sebagaimana disebutkan oleh Laurent Pech, ${ }^{20}$ bahwa penggunaan istilah rechtsstaat untuk pertama kalinya justru dikemukakan oleh Johan Wilhelm Placidus, ${ }^{21}$ dalam Literature der Staatslehre, Ein Versuch pada tahun 1798. Baru kemudian pada saat berlakunya Basic law Jerman pada tahun 1949, konsep rechsstaat berkembang sedemikian rupa sebagai prinsip yang lebih komprehensif dan secara tersirat lebih menyentuh prinsip-prinsip fundamental organisasi negara, yaitu seperti pemisahan kekuasaan, pengujian oleh badan peradilan, prinsip legalitas, prosedur yang adil, adanya kepastian hukum dan juga proporsionalitas serta sejumlah prinsip fundamental lainnya.

Sementara bila kemudian dilihat di Perancis, perkembangan konsep negara hukum ditandai dengan dua hal. Pertama, tidak terdapat padanan konsep rechtsstaat. Adapun istilah etat de droit sebagaimana dikenalkan oleh Leon Duguit pada tahun 1907 hanya sematamata merupakan terjemahan dari literal rechtsstaat. ${ }^{22}$ Artinya bahwa sesungguhnya tidak ditemukan makna yang sama persis dengan konsep rechtsstaat di Perancis. Kedua, konstitusionalisme Perancis tidak tumbuh dan mengakar secara kuat. Sebagaimana yang dikemukakan oleh Pech, ${ }^{23}$ bahwa selama masa Revolusi Perancis dan tahun-tahun berikutnya, bentuk dan sifat pemerintahan di Perancis selalu berubah-ubah, mulai dari sistem kerajaan yang konstitusional, republi, hingga kediktatoran dan kemudian pada akhirnya menuju restorasi kerajaan.

Roda perjalanan pemerintahan yang selalu berubah-ubah sebagaimana yang pernah dialami Perancis tentu tidak akan efektif untuk

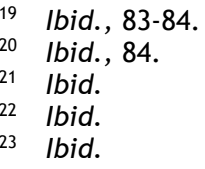

23 Ibid. 
mengukuhkan sebuah konsep kenegaraan seperti konsep negara hukum. Sebab bagaimanapun, terlalu seringnya bentuk dan sifat serta sistem pemerintahan suatu negara mengalami perubahan akan sangat banyak mempengaruhi konsep bernegara yang dibangun dalam negara itu sendiri. ${ }^{24}$

Di Indonesia, misalnya salah satu sistem yang pernah mengalami perubahan adalah terkait dengan penerapan demokrasi langsung, khususnya di tingkat lokal. Tidak tertutup kemungkinan bahwa di masa yang akan datang, proses pemilihan kepala daerah justru mengalami perubahan menuju sistem-sistem berikutnya. Bisa saja suatu ketika, sistem pemilihan kepala daerah di Indonesia akan dilakukan dengan sistem pengangkatan oleh pemerintah pusat atau mungkin kembali ke mekanisme pemilihan kepala daerah oleh DPRD setempat. Dinamika politik yang ada sangat memungkinkan hal itu terjadi, khususnya melihat fakta akan ketidakberhasilan proses pemilihan umum kepala daerah secara langsung dalam menghasilkan pemimpin daerah yang mampu menjawab tantangan otonomi daerah secara utuh dan menyeluruh. Sebaik apapun konsep negara hukum yang akan diusung, namun bila kemudian tidak ditemukan adanya sikap konsisten dalam membangun bentuk dan sistem serta manajemen pemerintahan, akan sangat sulit kiranya untuk me-wujudkan konsep dimaksud secara utuh dan menyeuruh.

Terlepas kemudian bagaimana perjalanan sejarah konsep negara hukum dalam arti rechtsstaat di berbagai negara, bila kemudian pembahasannya dikembalikan pada UUD 1945 sebelum perubahan yang mana telah ditegaskan bahwa konsep negara hukum yang dianut ketika itu adalah konsep negara hukum dalam arti rechtsstaat, maka kiranya makna negara hukum yang dianut dalam UUD 1945 dapat dilihat dari pendapat Hans Kelsen tentang syarat-syarat maupun ciri-ciri sebuah negara yang menganut rechtsstaat sebagaimana telah diuraikan sebe-

\footnotetext{
24 Janpatar Simamora, “Perlindungan Hak Memilih Sebagai Hak Konstitusional Warga Negara, Jurnal Yudisial, Vol. 6 No. 2, Edisi Agustus 2013, Jakarta: Komisi Yudisial Republik Indonesia, hlm. 128.
}

lumnya. Adapun ciri-ciri sekaligus syarat negara hukum dengan konsep rechtsstaat adalah sebagai berikut

Pertama, negara yang kehidupannya sejalan dengan konstitusi dan undang-undang yang proses pembuatannya dilakukan oleh parlemen. Ada dua hal yang sangat pokok dari ciri yang pertama ini, yaitu: (a) tampak adanya penegasan bahwa segala aktivitas pemerintahan dan kenegaraan harus disandarkan pada mekanisme yang sebelumnya telah diatur dalam konstitusi maupun dalam bentuk peraturan perun-dangundangan lainnya; (b) melalui ciri ini juga ditegaskan bahwa setiap proses pembentukan undang-undang dila-kukan oleh parlemen. Namun demikian, patut dicatat bahwa undang-undang yang dihasilkan oleh parlemen atau legislatif haruslah berupa produk yang seirama dan sejalan dengan aspirasi masyarakat, sebab bila tidak, maka produk tersebut akan sangat layak dijadikan sebagai musuh bersama (common enemy) oleh rakyat. ${ }^{25}$ Sebagaimana dikemukakan oleh Khopiatuziadah, ${ }^{26}$ dengan mengutip pandangan W. Friedman bahwa diperlukan adanya keseimbangan antara keinginan untuk membentuk pembaruan hukum melalui undangundang dengan kesadaran memperhatikan kenyataan hidup dalam masyarakat. Kenyataankenyataan ini di-sebut sebagai "living law dan just law" yang merupakan "inner order" dari masyarakat yang mencerminkan nilai-nilai hidup di dalamnya. Jadi dalam membentuk suatu undang-undang, agar undang-undang tersebut dapat berlaku secara efektif, maka dalam pembentukannya harus memperhatikan hukum yang hidup (living law) di tengah-tengah masyarakat itu sendiri.

Kedua, negara yang mengatur mekanisme pertanggungjawaban atas setiap kebijakan dan tindakan yang dilakukan oleh elite negara. Ciri

25 Abdul Wahid, "Politik Legislasi Menentukan Demokrasi (Analisis Putusan Nomor 15/PUU-IX/2011)", Jurnal Konstitusi, Vol. 9 No. 1, Edisi Maret 2012, Jakarta: Mahkamah Konstitusi Republik Indonesia, hlm. 164.

26 Khopiatuziadah, "Partisipasi Publik dalam Pembentukan Undang-Undang: Pijakan Berpikir Sosiologis Sebagai Landasan Pemikiran dalam Penyusunan Naskah Akademik", Jurnal Legislasi Indonesia, Vol. 10 No. 1, Edisi Maret 2013, Jakarta: Direktorat Jenderal Peraturan Perundang-undangan Kementerian Hukum dan HAM RI, hlm. 85. 
ini menegaskan bahwa negara berperan besar dalam menentukan arah kebijakan dan tindakan setiap elite negara. Bila hal ini dapat dijalankan dengan baik dan konsisten, maka dapat dipahami bahwa negara hukum dengan konsep rechtsstaat akan mampu membawa perubahan mendasar dalam rangka mensejahterakan kehidupan rakyat. Hal ini didasarkan pada pandangan bahwa negara dibentuk dalam rangka mewujudkan kesejahteraan rakyatnya, bukan kesejahteraan segelintir orang maupun sejumlah pihak yang sedang memangku kekuasaan.

Ketiga, negara menjamin kemerdekaan kekuasaan kehakiman. ${ }^{27}$ Selama ini di Indonesia dalam prak-tinya, tidak jarang hakim terbelah dalam dua tipe atau kelompok dalam menjalankan kewenangannya, khususnya dalam menangani perkara-perkara korupsi. Ada tipe "hakim tekstual" dan ada juga tipe "hakim kontekstual". Pemaknaan tekstual adalah penafsiran sempit hakim yang hanya mengacu pada teks peraturan perundang-undangan yang berlaku, sedangkan pemaknaan kontekstual adalah penafsiran luas yang dilakukan oleh hakim, di mana selain mengacu pada teks peraturan yang berlaku, juga turut mempertimbangkan faktorfaktor sosio-legal yang ada. Pola pikir hakim dengan pemaknaan tekstual masih mendominasi paradigma hakim dalam menafsirkan ketentuan peraturan perundang-undangan.

Ciri ketiga ini menunjukkan bahwa kekuasaan kehakiman dalam suatu negara dengan konsep rechtsstaat adalah salah satu unsur penting. Oleh sebab itu, maka kemerdekaan dan kemandirian serta independensi kekuasaan kehakiman di-jamin sepenuhnya oleh negara. Tiada seorangpun, termasuk penguasa yang dapat mencampuri kemerdekaan dan kebebasan kekuasaan kehakiman. Hal ini patut untuk ditegaskan agar kemudian lembaga pelaksana kekuasaan kehakiman mampu menjalankan tugas dan tanggungjawabnya dengan baik, khususnya dalam rangka mewujudkan pilar-pilar hukum,

27 M. Syamsudin, "Rekonstruksi Pola Pikir Hakim dalam Memutus kan Perkara Korupsi Berbasis Hukum Progresif", Jurnal Dinamika Hukum, Vol. 11 No. 1, Edisi Januari 2011, Purwokerto: Fakultas Hukum Universitas Jenderal Soedirman, hlm. 12. baik kepastian, keadilan maupun kemanfaatan hukum.

Independensi peradilan menurut Charles Gardner Geyh, setidaknya terda-pat tiga faktor pembenar mengenai independensi lembaga peradilan. Pertama, independensi hakim yang lebih baik terletak pada upaya menghormati dan menentukan proses hukum (due process). Kedua, independensi hakim yang lebih baik terletak dalam upaya mengelola keadilan pada kasus per kasus (justice on a case-by-case basis). Ketiga, independensi hakim tetap lebih mampu menegakkan dan menjunjung hukum (uphold the law). ${ }^{28}$ Independensi peradilan merupa-kan hal yang tidak bisa dipisahkan dari keberadaan suatu lembaga peradilan yang ideal. Peranan dari lembaga peradilan akan terdistorsi dan mengakibatkan turunnya kepercayaan publik kepada lembaga peradilan jika dalam pelaksanaannya, lembaga peradilan itu sendiri tidak mampu menjaga independensinya. ${ }^{29}$

Keempat, negara yang melindungi hak azasi manusia. ${ }^{30}$ Perlindungan negara terhadap hak asasi manusia (HAM) dapat dilihat dari perangkat hukum yang mengatur masalah HAM itu sendiri, sedangkan besar tidaknya negara menyediakan instrumen hukum terhadap persoalan HAM minimal diukur dengan banyaknya regulasi tentang HAM, baik berupa undang-undang mau pun Konvensi Internasional tentang HAM yang telah diratifikasi dan dimplementasikan pada suatu negara.

Ciri terakhir ini menegaskan bahwa negara hukum dengan konsep rechtsstaat juga menempatkan perlindungan maksimal terhadap hak-hak asasi atau hak-hak dasar manusia. Sebenarnya, negara dengan bentuk apapun di era modern ini, selalu menjadikan hak asasi manu-

28 Charles Gardner Geyh, "Judicial Selection Reconsidered: A Plea for Radical Mode-ration", Harvard Journal of Law \& Public Policy, Vol. 35 No. 2, Spring 2012, hlm. 626-628.

29 Dimas Prasidi, “Akses Publik Terhadap Informasi di Pengadilan”, Jurnal Konstitusi, Vol. 7 No. 3, Edisi Juni 2010, Jakarta: Mahkamah Konstitusi Republik Indonesia, hlm. 169.

30 Habib Shulton Asnawi, "Politik Hukum Putusan MK No. 46/PUU-VIII/2010 Tentang Status Anak di Luar Nikah: Upaya Membongkar Positivisme Hukum Menuju Perlindungan HAM", Jurnal Konstitusi, Vol. 10 No. 2, Edisi Juni 2013, Jakarta: Mahkamah Konstitusi Republik Indonesia, hlm. 245. 
sia sebagai salah satu isu yang patut mendapat perlindungan secara maksimal. Namun demikian, dengan penegasan ini, tampak dengan jelas bahwa negara hukum dengan konsep rechtsstaat menjunjung tinggi perlindungan terhadap hak asasi manusia.

Inilah sejumlah ciri negara hukum dengan konsep rechtsstaat sebagaimana dimaksud dalam UUD 1945 sebelum perubahan. Tentu tidak dapat dipungkiri bahwa dengan mencermati sejumlah ciri dimaksud, maka kemungkinan akan memunculkan pertanyaan yang cukup esensial terkait dengan roda perjalanan pemerintahan di era pemberlakuan UUD 1945 sebelum perubahan. Kalau memang demikian makna negara hukum yang terkandung dalam UUD 1945 sebelum perubahan, apakah realitanya sudah berbanding lurus ketika itu.

Hal ini tentunya akan dapat dijawab dengan memutar ulang memori pikiran publik tentang bagaimana roda perjalanan pemerintahan ketika itu. Harus diakui bahwa khususnya selama rezim orde baru yang terkenal dengan keotoriterannya, sejumlah ciri-ciri negara hukum dimaksud sangatlah sulit untuk direalisasikan. Rezim pemerintahan kala itu terkesan hanya menempatkan UUD 1945 sebagai naskah tekstual semata, tidak dibarengi dengan tindakan dan perbuatan nyata dalam rangka merealisasikannya dalam kehidupan berbangsa dan bernegara.

Sekalipun sangat sulit menarik garis lurus antara ciri pokok negara hukum dalam arti rechtsstaat dengan realitas yang ada ketika itu, bukan berarti bahwa sejumlah ciri dimaksud dapat dipersalahkan sedemikian rupa. Kalau dapat dikatakan secara jujur, bahwa makna negara hukum dalam arti rechtsstaat sebagaimana diadopsi dalam UUD 1945 sebelum perubahan dapat dikatakan sebagai salah satu konsep ideal suatu negara. Kalau kemudian dalam praktiknya di lapangan justru berkata lain, atau bahkan bertolak belakang, maka hal ini harus disikapi secara bijak dengan melihat persoalan dimaksud sebagai persoalan lain yang tidak ada tali temali kelahirannya dengan konsep negara hukum dalam pemaknaan rechtsstaat.
Patut dipersoalkan dari kondisi yang demikian adalah rezim pemerintahan yang memegang tampuk kekuasaan. Kalaupun harus dievaluasi, maka watak rezim yang berkuasalah yang harus dievaluasi. Atas dasar itulah maka kemudian bergolak arus reformasi pada tahun 1997-1998 yang kemudian berhasil menumbangkan rezim orde baru yang dianggap tidak menjalankan prinsip-prinsip kenegaraan dan pemerintahan sebagaimana telah digariskan dalam konstitusi. Sekalipun kemudian tuntutan reformasi berhasil mengubah konsep negara hukum di tanah air, namun hal itu tidak dapat dengan sendirinya dimaknai bahwa bangsa Indonesia tidak menyetujui pengadopsian negara hukum dalam arti rechtsstaat.

\section{Makna Negara Hukum Menurut UUD NRI Ta- hun 1945}

Pengaturan mengenai negara hukum dalam UUD NRI Tahun 1945 ditempatkan melalui Pasal 1 ayat (3), yang menentukan bahwa $\mathrm{Ne}$ gara Indonesia adalah negara hukum. Setidaknya, terdapat dua makna besar yang dapat dipahami dari pemindahan ketentuan ini dari yang sebelumnya ditempatkan di dalam bagian "Penjelasan" UUD 1945 sebelum perubahan, kemudian diletakkan dalam bagian "Pasal-Pasal" dalam UUD NRI Tahun 1945. Makna per-tama adalah bahwa pemindahan ketentuan mengenai negara hukum ke dalam bagian "PasalPasal" menunjukkan adanya upaya penegasan terhadap konsep negara hukum bagi Indonesia. Dengan pemindahan dimaksud ke dalam bagian "Pasal-Pasal", maka diharapkan daya ikat mengenai ketentuan negara hukum bagi Indonesia akan semakin kuat. Kedua, pemindahan dimaksud juga dapat dimaknai sebagai upaya untuk menegaskan kembali bahwa bangsa Indonesia secara sungguh-sungguh akan melandaskan seluruh aktivitas kehidupan berbangsa dan bernegara pada ketentuan hukum yang ada. Hukum akan menjadi panglima sekaligus rambu pembatas bagi setiap tindakan pemerintah dan rakyat dalam mengelola bangsa dan negara.

Langkah pengaturan ketentuan mengenai negara hukum dimaksud dengan menghilangkan istilah rechtsstaat setidaknya mengandung dua 
konsekuensi tersendiri yang saling bertolak belakang. Pertama, bentuk dan pola pengaturan yang demikian akan memudahkan bangsa Indonesia dalam menerjemahkan apa sesungguhnya yang dimaksud dengan negara hukum sesuai dengan keinginan dan kehendak bangsa Indonesia. Dengan dihilangkannya istilah rechtsstaat, hal ini menunjukkan bahwa Indonesia tidak terikat pada konsep negara hukum sesuai dengan syarat-syarat yang dijalankan dalam konsep negara hukum dalam arti rechtsstaat. Konsekuensi pertama ini dapat dikategorikan sebagai konsekuensi yang bersifat negatif. Konsekuensi kedua dari penghilangan istilah rechtsstaat dari UUD adalah bahwa negara hukum yang dimaksud dalam UUD menjadi sulit untuk ditafsirkan secara konkret, apakah negara hukum dalam arti rule of law atau negara hukum dalam arti rechtsstaat atau kedua-duanya. Konsekuensi kedua ini barangkali lebih tepat disebut sebagai konsekuensi yang bersifat negatif.

Hal tersebut menimbulkan pertanyaan, apakah sesungguhnya makna dari negara hukum sebagaimana yang dimaksud dalam Pasal 1 ayat (3) UUD NRI Tahun 1945. Apakah negara hukum dalam arti rechtsstaat atau negara hukum dalam pemaknaan the rule of law, ataukah ada makna lain yang tidak termasuk ke dalam dua aliran utama negara hukum itu. Persoalan ini masih menjadi bahan perdebatan banyak pihak, khususnya para pegiat Hukum Tata Negara di tanah air.

Indonesia Legal Rountable menjelaskan, ${ }^{31}$ bahwa setidaknya terdapat lima prinsip dan indikator negara hukum. Pertama, pemerintahan berdasarkan hukum, dengan indikator adanya keseimbangan di antara cabang-cabang kekuasaan eksekutif, legislatif dan yudikatir serta performa eksekutif dan legislatif; kedua, independensi kekuasaan kehakiman, dengan indikator pelaksana dan organisasi kekuasaan kehakiman itu sendiri; ketiga, penghormatan, pengakuan dan perlindungan hak asasi manusia, dengan indikator kebebasan untuk berserikat, berkumpul serta menyatakan pendapat, kebe-

31 Tim Indonesian Legal Rountable, 2013, Indeks Persepsi Negara Hukum Indonesia 2012, Jakarta: Indonesian Legal Rountable, hlm. 8-9. basan beragam dan berkeyakinan, perlakuan yang tidak diskriminatif, hak untuk hidup dan bebas dari penyiksaan, hak atas pekerjaan, upah yang layak dan pendidikan; keempat, akses terhadap keadilan, dengan indikator peradilan yang mudah, cepat dan berbiaya ringan, bantuan hukum kepada warga yang tidak mampu, perlindungan kepada korban, pelapor dan kompensasi kepada yang dinyatakan bersalah secara keliru; dan kelima, peraturan yang terbuka dan jelas, dengan indikator mengikutsertakan publik dalam pembuatan peraturan, kejelasan materi peraturan dan akses terhadap peraturan perundang-undangan itu sendiri.

Harus diakui bahwa penegasan negara hukum Indonesia menurut UUD NRI Tahun 1945 tidak harus dilihat sebagai suatu bangunan yang final, tetapi merupakan suatu bangunan yang secara terus menerus harus dibenahi untuk mencapai Indonesia yang sesungguhnya. Misalnya, perlu dipertimbangkan sejauhmana harmonisasi hubungan hukum adat dan hukum nasional dalam proses membangun negara hukum Indonesia. ${ }^{32}$ Namun demikian, bersamaan dengan menjalankan roda pembangunan hukum di tanah air, haruslah dimaknai setiap perubahan yang terkandung dalam konstitusi secara jelas dan tegas, agar kemudian dalam implementasinya tidak menimbulkan persoalan.

Rujukan yang paling tepat dijadikan sebagai landasan berpikir dalam rangka menjawab tafsir makna negara hukum dalam perspektif UUD NRI Tahun 1945 adalah dengan memahami kembali secara utuh substansi pembukaan UUD itu sendiri, khususnya alinea keempat. Adapun bunyi alinea keempat Pembukaan UUD 1945 adalah sebagai berikut:

Kemudian daripada itu untuk membentuk suatu Pemerintah Negara Indonesia yang melindungi segenap bangsa Indonesia dan seluruh tumpah darah Indonesia dan untuk memajukan kesejahteraan umum, mencerdaskan kehidupan bangsa, dan ikut melaksanakan ketertiban dunia yang berdasarkan kemerdekaan, perdamaian abadi dan keadilan sosial, maka disusun-

32 Yanis Maladi, "Eksistensi Hukum Adat dalam Konstitusi Negara Pasca Amandemen", Jurnal Mimbar Hukum, Vol. 22 No. 3, Edisi Oktober 2010, Yogyakarta: Fakultas Hukum UGM, hlm. 458. 
lah Kemerdekaan Kebangsaan Indonesia itu dalam suatu Undang-Undang Dasar Negara Indonesia, yang terbentuk dalam suatu susunan Negara Republik Indonesia yang berkedaulatan rakyat dengan berdasar kepada Ketuhanan Yang Maha Esa, Kemanusiaan yang adil dan beradab, Persatuan Indonesia dan Kerakyatan yang dipimpin oleh hikmat kebijaksanaan dalam permusyawaratan/Perwakilan, serta dengan mewujudkan suatu Keadilan sosial bagi seluruh rakyat Indonesia.

Dilihat dari substansi ketentuan dimaksud, cukup jelas dan tegas disebutkan bahwa pemerintah negara Indonesia dibentuk dalam rangka melindungi segenap bangsa Indonesia dan seluruh tumpah darah Indonesia. Tujuannya kemudian adalah dalam rangka memajukan kesejahteraan umum; mencerdaskan kehidupan bangsa; dan ikut serta dalam upaya pelaksanaan ketertiban dunia yang didasarkan pada kemerdekaan, perdamaian abadi dan keadilan sosial. Adapun pelaksanaan roda pemerintahan dan dan negara Republik Indonesia harus didasarkan pada prinsip-prinsip dasar yang berkedaulatan rakyat dengan berdasar kepada Ketuhanan Yang Maha Esa, Kemanusiaan yang adil dan beradab, Persatuan Indonesia dan Kerakyatan yang dipimpin oleh hikmat kebijaksanaan dalam permusyawaratan/perwakilan, serta dengan mewujudkan suatu Keadilan sosial bagi seluruh rakyat Indonesia. Bunyi alinea ke-4 Pembukaan UUD 1945, dengan menempatkan frasa 'memajukan kesejahteraan umum' adalah merupakan salah satu cita negara Republik Indonesia dan merupakan cikal bakal munculnya konsepsi negara kesejahteraan di Indo-nesia. ${ }^{33}$

Bunyi kalimat terakhir ini adalah merupakan isi dari apa yang dinamakan dengan istilah Pancasila. Mendasarkan pada ketentuan dimaksud, maka dapat dipahami kemudian bahwa negara hukum yang dimaksud dalam UUD NRI Tahun 1945 adalah negara hukum yang pelaksanaannya mendasarkan pada upaya pemenuhan seluruh ketentuan yang tertuang dalam ali-

33 Kukuh Fadli Prasetyo, "Politik Hukum di Bidang Ekonomi dan Pelembagaan Konsepsi Welfare State di dalam Undang-Undang Dasar 1945", Jurnal Konstitusi, Vol. 9 No. 3, Edisi September 2012, Jakarta: Mahkamah Konstitusi Republik Indonesia, hlm. 495. nea keempat Pembukaan UUD 1945. Oleh karena itulah, maka kemudian negara hukum dalam versi UUD NRI Tahun 1945 dapat dimaknai sebagai negara hukum Pancasila.

Cita hukum negara Indonesia bersumber dari Pancasila yang merupakan filosofische gronslag dan common platform sebagai dasar negara. Oleh sebab itu, maka aktivitas lembaga pembuat hukum harus dimuarakan pada nilainilai common platform tersebut yang sarat dengan budaya, nilai-nilai yang hidup dalam masyarakat atau kearifan-kearifan lokal (local wisdom) yang melekat di dalamnya. Bahkan seyogianya dalam sistem hukum Pancasila, negara hukum yang dibangun harus dapat memadukan secara harmonis unsur-unsur dari rechtsstaat (kepastian hukum) dan the rule of law (keadilan substansial). ${ }^{34}$ Dengan berpedoman pada hal tersebut, maka negara hukum Pancasila mengandung unsur-unsur utama sebagai berikut. Pertama, negara yang ber-Ketuhanan Yang Maha Esa; kedua, pemerintahan yang didasarkan pada hukum; ketiga, penguatan prinsip demokrasi dalam memilih para pemimpin; keempat, adanya pembatasan kekuasaan pemerintahan dengan mengedepankan prinsip checks and balances; kelima, prinsip persamaan di depan hukum (equality before the law); keenam, diakuinya kekuasaan kehakiman yang merdeka dalam menyelenggarakan peradilan guna menegakkan hukum dan keadilan; ketujuh, adanya peradilan tata negara dan peradilan tata usaha negara; dan kedelapan, adanya pengakuan dan perlindngan terhadap hak-hak dasar atau hak asasi manusia; serta kesembilan, adanya upaya untuk mewujudkan negara kesejahteraan (welfare state).

Secara umum masyarakat merasa telah merdeka dalam menyatakan pendapat dan keinginan. Kemerdekaan serupa dirasakan dalam keikutsertaan secara aktif pada organisasi sosial dan politik. Dalam artian tertentu fakta ini bisa diartikan sebagai efektivitas implementasi se-

34 Wahyu Nugrono, "Menyusun Undang-Undang yang Responsif dan Partisipatif Berdasarkan Cita Hukum Pancasila", Jurnal Legislasi Indonesia, Vol. 10 No. 3, Edisi September 2013, Jakarta: Direktorat Jenderal Peraturan Perundang-undangan Kementerian Hukum dan HAM RI, hlm. 212. 
bagian peraturan perundang-undangan yang menjamin kebebasan berserikat, berkumpul, dan menyatakan pendapat. Namun, studi dokumen juga mengungkapkan bahwa pada saat yang sama masih terdapat sejumlah peraturan perundangan yang bersifat membatasi hak menyatakan pendapat. Secara umum masyarakat juga menilai bahwa para pekerja pers telah mendapatkan perlindungan dari Negara terutama saat meliput atau menyajikan berita. ${ }^{35}$

Berkaitan dengan paham welfare state, Paham welfare state yang dianut oleh suatu negara biasanya mencantumkan bentuk-bentuk kesejahteraan dalam pasal-pasal konstitusi atau undang-undang dasar negaranya. Bila kemudian dilihat di Indonesia, maka salah satu sarana penting dalam upaya mewujudkan kesejahteraan adalah mewujudkankan "keadilan sosial" sebagaimana ditegaskan dalam sila ke-5 Pancasila yang kemudian dijabarkan secara eksplisit di dalam alinea IV Pembukaan UUD $1945 .{ }^{36}$ Konsepsi Welfare state diasosiasikan dengan pemenuhan kebutuhan dasar, oleh karena itu konsep ini dianggap sebagai mekanisme pemerataan terhadap kesenjangan yang ditimbulkan oleh ekonomi pasar. ${ }^{37}$

Berdasarkan hasil survei Indonesian Legal Rountable tahun 2012, ${ }^{38}$ bahwa untuk indikator pelaksana Kekuasaan Kehakiman misalnya, tingginya laporan masyarakat mengenai dugaan adanya pelanggaran kode etik oleh hakim dan pegawai pengadilan sejalan dengan hasil survei yang menunjukan bahwa sebagian besar masyarakat masih berpendapat hakim tidak bebas dari suap dan dapat diintervensi oleh pihak lain pada saat menjalankan tugasnya. Sejumlah unsur-unsur dimaksud hanyalah merupakan unsurunsur pokok yang patut digaris bawahi dalam negara hukum Pancasila, sebab di samping itu,

35 Menurut hasil survei Indonesian Legal Rountable tahun 2012, Op.Cit., hlm. 177.

36 Marilang, "Ideologi Welfare State Konstitusi: Hak Menguasai Negara Atas Barang Tambang", Jurnal Konstitusi, Vol. 9 No. 2, Edisi Juni 2012, Jakarta: Mahkamah Konstitusi Republik Indonesia, hlm. 267.

37 Alfitri, "Ideologi Welfare State dalam Dasar Negara Indonesia: Analisis Putusan Mahkamah Konstitusi Terkait Sistem Jaminan Sosial Nasional", Jurnal Konstitusi, Vol. 9 No. 3, Edisi September 2012, Jakarta: Mahkamah Konstitusi Republik Indonesia, hlm. 454.

38 Tim Indonesian Legal Rountable, op.cit., hlm. 176. masih dapat diuraikan lebih lanjut unsur-unsur lain yang lebih rinci seperti prinsip pembagian kekuasaan dan sejumlah unsur lainnya. Oleh sebab itu, maka bila seluruh unsur-unsur yang terkandung dalam negara hukum Pancasila sebagaimana maksud maupun makna negara hukum dalam UUD NRI Tahun 1945, maka sesungguhnya negara hukum Pancasila dapat dikatakan lebih kompleks dan ideal, setidaknya untuk ukuran bangsa Indonesia dibanding dengan negara hukum dalam arti rechtsstaat maupun negara hukum dalam arti the rule of law, khususnya bila dikaitkan dengan situasi dan kondisi bangsa Indonesia.

Perlu dipersoalkan kemudian adalah sejauhmana keseriusan pemerintah dalam menjalankan amanat negara hukum Pancasila dimaksud. Sekalipun suatu konsep dapat dikatakan sudah dibangun seideal dan sekomprehensif mungkin. Namun bila dalam tataran implementasi masih jauh panggang dari api, maka konsep-konsep ideal dimaksud tidak akan berkontribusi besar bagi kehidupan berbangsa dan bernegara di tanah air. Bagaimanapun idealnya negara hukum Pancasila, kalau tidak dibarengi dengan kesungguhan maupun keseriusan dalam mewujudnyatakannya, maka hal itu tidak akan berkorelasi positif dalam upaya pencapaian tujuan berbangsa dan bernegara sebagaimana telah digariskan oleh para the founding fathers kita dalam alinea keempat Pembukaan UUD 1945.

\section{Penutup}

Pasal 1 ayat (3) UUD NRI Tahun 1945 dengan tegas mengamanatkan bahwa negara Indonesia adalah negara hukum. Ketentuan ini sama sekali tidak menguraikan lebih lanjut makna negara hukum yang menjadi acuan bagi Indonesia, apakah negara hukum dalam arti rechtsstaat atau negara hukum dalam arti the rule of law sebagai dua aliran negara hukum yang selama ini dikenal di berbagai belahan dunia. $\mathrm{Na}$ mun demikian, dengan memperhatikan substansi yang terkandung dalam alinea keempat Pembukaan UUD 1945, maka dapat dipahami bahwa makna negara hukum yang dimaksudkan dalam Pasal 1 ayat (3) UUD NRI Tahun 1945 
adalah negara hukum Pancasila, yaitu negara hukum yang didasarkan pada bunyi Pancasila. Artinya bahwa Indonesia memiliki pemaknaan tersendiri dalam menentukan ciri negara hukum Indonesia.

Substansi yang terkandung dalam negara hukum Pancasila sangatlah ideal dan kompreshensif, sekalipun kemudian dibandingkan dengan negara hukum dalam arti rechtsstaat atau negara hukum dalam arti the rule of law. Namun demikian, konsep negara hukum Pancasila yang ideal itu tidak akan dapat berkontribusi besar bagi kehidupan berbangsa dan bernegara tanpa dibarengi keseriusan dalam merealisasikannya, maka kiranya seluruh elemen bangsa, khususnya pemegang tampuk kekuasaan di tanah air harus menjiwai dan memahami serta memiliki kemauan dan tekad yang sungguhsungguh dalam mewujudkan negara hukum yang mengedepankan nilai-nilai luhur Pancasila.

\section{Daftar Pustaka}

Alfitri. “Ideologi Welfare State dalam Dasar Negara Indonesia: Analisis Putusan Mahkamah Konstitusi Terkait Sistem Jaminan Sosial Nasional”. Jurnal Konstitusi. Vol. 9 No. 3. Edisi September 2012. Jakarta: Mahkamah Konstitusi Republik Indonesia;

Asnawi, Shulton, Habib. "Politik Hukum Putusan MK No. 46/PUU-VIII/2010 Tentang Status Anak di Luar Nikah:Upaya Membongkar Positivisme Hukum Menuju Perlindungan HAM". Jurnal Konstitusi. Vol. 10 No. 2. Edisi Juni 2013. Jakarta: Mahkamah Konstitusi Republik Indonesia;

Dayanto. “Rekonstruksi Paradigma Pembangunan Negara Hukum Indonesia Berbasis Pancasila". Jurnal Dinamika Hukum. Vol. 13 No. 3. Edisi September 2013. Purwokerto: Fakultas Hukum Universitas Jenderal Soedirman;

Geyh, Gardner, Charles. "Judicial Selection Reconsidered: A Plea for Radical Moderation". Harvard Journal of Law \& Public Policy. Vol. 35 No. 2. Spring 2012;

Goldstein, K, Joel. "Constitutional Change. Originalism and The Vice Presidency". Journal of Constitutional Law. University of Pennsylvania Law of School. Philadelphia. Vol. 16 No. 2. Nov. 2013;
Harijanti, Dwi, Susi. 2011. Negara Hukum dalam Undang-Undang Dasar 1945. dalam "Negara Hukum yang Berkeadilan: Kumpulan Pemikiran dalam Rangka Purnabakti Prof.Dr.H.Bagir Manan. SH.. MCL". Cetakan Pertama. Bandung: PSKN FH UNPAD;

Khopiatuziadah. "Partisipasi Publik dalam Pembentukan Undang-Undang: Pijakan Berpikir Sosiologis Sebagai Landasan Pemikiran dalam Penyusunan Naskah Akademik". Jurnal Legislasi Indonesia. Vol. 10 No. 1. Edisi Maret 2013. Jakarta: Direktorat Jenderal Peraturan Perundang-undangan Kementerian Hukum dan HAM RI;

Kurnia, Slamet, Titon. “Konsep Negara Berbasis Hak sebagai Argumen Justifikasi Pengujian Konstitusionalitas Undang-undang". Jurnal Konstitusi. Vol. 9 No. 3. Edisi September 2012. Jakarta: Mahkamah Konstitusi Republik Indonesia;

Maladi, Yanis. "Eksistensi Hukum Adat dalam Konstitusi Negara Pasca Amandemen". Jurnal Mimbar Hukum. Vol. 22 No. 3. Edisi Oktober 2010. Yogyakarta: Fakultas Hukum UGM;

Marilang. "Ideologi Welfare State Konstitusi: Hak Menguasasi Negara Atas Barang Tambang". Jurnal Konstitusi. Vol. 9 No. 2. Edisi Juni 2012. Jakarta: Mahkamah Konstitusi Republik Indonesia;

MPR RI. 2012. Panduan Pemasyarakatan Undang-Undang Dasar Negara Republik Indonesia Tahun 1945 dan Ketetapan Majelis Permusyawaratan Rakyat. Edisi Revisi. Cetakan Kesebelas. Jakarta: Sekretariat Jenderal MPR RI;

Nugrono, Wahyu. "Menyusun Undang-Undang yang Responsif dan Partisipatif Berdasarkan Cita Hukum Pancasila”. Jurnal Legislasi Indonesia. Vol. 10 No. 3. Edisi September 2013. Jakarta: Direktorat Jenderal Peraturan Perundang-undangan Kementerian Hukum dan HAM RI;

Prasetyo, Kukuh Fadli. “Politik Hukum di Bidang Ekonomi dan Pelembagaan Konsepsi Welfare State di dalam Undang-Undang $\mathrm{Da}$ sar 1945". Jurnal Konstitusi. Vol. 9 No. 3. Edisi September 2012. Jakarta: Mahkamah Konstitusi Republik Indonesia;

Prasidi, Dimas. "Akses Publik Terhadap Informasi di Pengadilan". Jurnal Konstitusi. Vol. 7 No. 3. Edisi Juni 2010. Jakarta: Mahkamah Konstitusi Republik Indonesia; 
Rogers, James Kenneth. "The Other Way to Amend the Constitution: The artikel $V$ Constitutional Convention Amendment Process". Harvard Journal of Law \& Public Policy. Vol. 30 No.3. Summer 2007;

Siahaan, Maruarar. "Uji Konstitusionalitas Peraturan Perundang-undangan Negara Kita: Masalah dan Tantangan". Jurnal Konstitusi. Vol. 7 No. 4. Edisi Agustus 2010. Jakarta: Mahkamah Konstitusi Republik Indonesia;

Simamora, Janpatar. 2013. Mendesain Ulang Model Kewenangan Judicial Review di Indonesia. Cetakan Pertama. Yogyakarta: Capiya Publishing;

. "Perlindungan Hak Memilih Sebagai Hak Konstitusional Warga Negara. Jurnal Yudisial. Vol. 6 No. 2. Edisi Agustus 2013. Jakarta: Komisi Yudisial Republik Indonesia;

Syamsudin, M. “Rekonstruksi Pola Pikir Hakim dalam Memutuskan Perkara Korupsi Berbasis Hukum Progresif". Jurnal Dinamika Hukum. Vol. 11 No. 1. Edisi Januari 2011. Purwokerto: Fakultas Hukum Universitas Jenderal Soedirman;

Tim Indonesian Legal Rountable. 2013. Indeks Persepsi Negara Hukum Indonesia 2012. Jakarta: Indonesian Legal Rountable;

Wahid, Abdul. "Politik Legislasi Menentukan Demokrasi (Analisis Putusan No. 15/PUU-IX/ 2011)”. Jurnal Konstitusi. Vol. 9 No. 1. Edisi Maret 2012. Jakarta: Mahkamah Konstitusi Republik Indonesia;

Zazili, Ahmad. "Pengakuan Negara Terhadap Hak-Hak Politik (Right to Vote) Masyarakat Adat dalam Pelaksanaan Pemilihan Umum (Studi Putusan Mahkamah Konstitusi No.47-81/P.A-V/2009)". Jurnal Konstitusi. Vol. 9 No. 1 Maret 2012. Jakarta: Mahkamah Konsitusi Republik Indonesia. 